\title{
Despoliated Ecosystem and the Exploited Woman: Victims or Volunteers? A Reading of Kaine Agary's Yellow-Yellow
}

\author{
Uchenna Ohagwam ${ }^{1}$ \\ ${ }^{1}$ Department of English Language and Literature, Rivers State University, Nigeria \\ Correspondence: Uchenna Ohagwam, Department of English Language and Literature, Rivers State University, \\ Nigeria. E-mail: uche.ohagwam@gmail.com
}

Received: May 1, 2021

Accepted: June 4, 2021

Online Published: June 10, 2021

doi:10.20849/aes.v6i1.930

URL: https://doi.org/10.20849/aes.v6i1.930

\begin{abstract}
The horrendous situation in the Niger Delta region of Nigeria is gradually producing a rich and enduring literature, which paints a vivid picture of the trauma of living in that part of the world. Playwrights, poets, dramatists and literary critics have all lent their contributions in a determined effort at speaking up against the enormity of the environmental degradation in the region; a tragedy brought about by the insensitive exploitation of the region's natural resources by multinational oil corporations. This study seeks to examine Kaine Agary's perspective towards the problem as captured in her fictional work, Yellow-Yellow, with focus on the heavy toll it takes on the woman. The dilemma of being caught in the web of either a victim or a volunteer, compels the woman to either dependency or independence. Thus, the paper concludes by making a case for economic independence and argues that it is the surest security for women, especially, the Niger Delta woman.
\end{abstract}

Keywords: despoliation, losses, victims, volunteers, education

\section{Introduction: Kaine Agary's Yellow Yellow}

Delta State-born, Kaine Agary, engaging the tools of ecofeminism, churned out a true-to-life story of the wounds of a despoiled ecosystem and the exploited woman in her 2006 award-winning fiction, Yellow-Yellow. Yellow-Yellow, is a Nigerian fiction dealing with some of the issues that constitute huge social threat in the Niger Delta region. Such issues as environmental degradation, poverty, lack of basic amenities, insecurity, betrayal, to give a short list of them. Although Kaine Agary did not choose to do creative writing from the outset, but research and its attendant field work during her master's degree programme in Public Policy, exposed her to the plight of the people who live and get their sustenance in the coastal parts of Nigeria. From her findings, she was compelled to not only express awareness and sympathy, but to fictionally document the unhealthy living conditions of many rural dwellers in Nigeria's Niger Delta and the combined efforts of government, the multinationals and selfish indigenous community leaders in multiplying the woes of the people in that region.

Written in a bildungsroman style, Yellow Yellow opens with the experience of a young mixed-race girl by the name Yellow-Yellow or Zilayefa who was raised briefly in an Ijaw community by her single mother, Bibi who stretches herself to afford basic education for her daughter, but was unfortunate. Bibi lost her Greek lover who left Nigeria without saying a good-bye; she also lost her farmland to crude oil pipeline explosion.

\section{The Gradual Destruction of the Ecosystem}

Can environmental damages translate into economic loss? Of course, it can. Reporting on her mother's economic loss, Zilayefa, the narrative voice and protagonist, explained:

And so it was that, in a single day,hl my mother lost her main source of sustenance. However, I think she had lost that land a longtime ago, because each season before. Not unlike the way she and others in the village had gradually lost, year after year, the creatures of the rivers to oil spills, acid rain, gas flares... (Yellow-Yellow p. 4).

As an eyewitness, she further recounted:

I watched as the thick liquid spread out, covering more land and drowning small animals in its path. It just kept spreading and I wondered if it would stop, when it 
would stop, how far it would spread. Then there was the smell. I can't describe it but it was strong-so strong it made my head hurt and turned my stomach. I bent over and retched so hard I became dizzy (p.4).

When you listen to a witness, you will become a witness; and one eyewitness is better than ten hear-sayers. The testimony or account of an eyewitness can be extremely compelling, such that his or her audience would find it difficult to take it lightly or adjust its impact. Studies have shown that eyewitness account is perhaps the most persuasive form of evidence when presented.

But what is the testimony of this teenager, Zilayefa? Her testimony is a harrowing description of the tragedy which hits her mother and her community in a single day. Tragedy, as conceived here is not traditional tragedy because Bibi (Zilayefa's mother) was not a noblewoman, not of any high social standing. Hence, her ordeal can be situated withing the scope of modern tragedy, the reverse of traditional tragedy. Modern tragedy is tragedy which arises not because of the nobility or high social standing of an individual, but by the sheer fact of being caught up in a tragic circumstance.

The concept of modern tragedy is traceable to an American scholar, Arthur Miller whose essay, "Tragedy and the Common Man" (1949), argued that tragedy is not an exclusively reserved for the high and mighty in the society. Miller's estimation is that the common man in society fits perfectly for a tragic mode of life. He pointedly observed:

...the inevitable conclusion is of course, that the tragic mode is archaic, fit only for the highly placed, the kingly, and where this admission is not made in so many words, it is most often implied. I believe that the common man is apt a subject for tragedy in the highest sense as kings were. On the surface of it this ought to be obvious in the light of modern psychiatry, which bases its analysis upon classic formulations, such as Oedipus and Orestes complexes for instances, which were enacted by royal beings, but which apply to everyone in similar emotional situations ("Tragedy and the Common Man" p. vii).

In the play, Death of a Salesman (1949), Arthur Miller tells the tragic story of a man who gave his life or perhaps, sold it in pursuit of the American dream. The play dramatizes tragedy from the standpoint of a common man as against nobility and royalty. Having portrayed the struggles, poverty and death of Willy Loman, the protagonist in Death of a Salesman, Millier contends that situations as this also elicits a tragic feeling in the audience and not only the fall of Oedious or Julius Caesar. According to him (Miller), “...the tragic feeling is evoked in us when we are in the presence of a character who is ready to lay down his life, if need be, to secure one thing..." ("Tragedy and the Common Man" p. viii).

By accessing Bibi's world, one would not just be found sympathizing, but also empathize with this young woman caught in the web of trying to secure her life and the life of her daughter in a toxic environment. One of the ways of understanding people's ordeal, is through empathy. Empathy is seeing with the eyes of another; it is listening with the ears of another, and it is feeling with the heart of another.

The motivation for this paper was aroused after I read these lines in the novel: “....in a single day, my mother lost her main source of sustenance" (Yellow-Yellow p. 4). This loss is indeed a loss too many; it is both an economic and a social; and this is in line with Miller's reasoning: "The tragic right is a condition of life; the condition in which the human personality s able to flower and realise itself." ("Tragedy and the Common Man" p. viii). The economic side is the polluted farmland; while the social is the loss of her Greek lover, Plato.

Without arguments, Zilayefa is a witness - a witness to tears, a witness to losses, a witness to exploitation, a witness to the curse pronounced on the Niger Delta region by crude oil itself: "The land cracks from loneliness/The farms swallowed by bitter spills/The rivers stagnated by oily curses..." (Floating Snags p. 22). The whole situation is economically tragic, by a simple evaluation; however, this tragedy did not take an immediate toll on the living standards of Bibi and her only child, but the downturn was gradual, attritional, unfolding as the days go by. This is in consonance with what Rob Nixon (2011) described as slow violence or violence of postponed effects.

Tracing the genesis of Bibi's ordeal or the violence she witnessed, one can apprehend the truth that it began when she met a male character, her Greek lover, the man who offered her love from Greece, but unknown to her that it was not love, but a Greek gift. A Greek gift is a gift given with the intention of tricking and causing harm on the recipient. Reporting on how ignorant and naïve her mother (Bibi) was to discern this Greek gift, Zilayefa remarked:

After months at sea, he (the Greek man) was just happy to see a woman and would have told her anything to have her company. The woman he chose was my mother, a young and naïve 
eighteen-year-old who had just moved to Port Harcourt from her small village with visions of instant prosperity. She had completed her secondary-school education and had passed her school-leaving examinations. With that qualification, she hoped to get a good job in Port Harcourt (Yellow-Yellow p. 7).

No doubt, Bibi's contact with this Greek man did not only drown her hope of securing a good job but marked the beginning of her end in her quest to advance her education. Although a female child became the product of that illegitimate and short-lived relationship, yet her frustration and depression were further heightened with the daily demands of rising that child as a poor single mother. It is against this background that feminist writers have argued that western civilization is pervasively patriarchal, that is, male-centred, and runs in a way that subordinates the woman, such that many women even co-operate and contribute to their own subordination or undoing. Zilayefa, the narrative voice and only child of Bibi recounted what could pass for the love story behind her Greek father and her young mother:

For the few weeks that he was in Port Harcourt, she was in heaven, she believed that she had found her life partner and that this man would take care of her. I don't think my father ever told her that he would marry her; she just assumed that he would (Yellow-Yellow p. 7)

Clearly, this assumption was her greatest undoing; it becomes her point of departure in her journey into sorrow and poverty. This sexual exploitation she suffered as an eighteen years old girl, is synonymous with the huge exploitation carried out by oil multinationals operating in the Niger Delta region of Nigeria. Apparently, Agary's novel has the qualities of aesthetic elegance that can take her in future to the pantheon of the likes of South African's Nobel Laureate, Nadine Gordimer ("Revolutionary," p. 15).

A bildungsroman is the account of the growing up of a sensitive young individual, who embarks on a mission to provide answers to some nagging questions that surrounds him or her, using different experiences or encounters. According to German philosopher, Georg Wilhelm Friedrich Hegel, "contradictions, tensions, paradoxes, oppositions and reversals are at the heart of all thought and even reality itself" (cited in Lawhead, p. 2002) and these constitute the content of a typical bildungsroman.

Permit me to argue that contradiction is the form of violence Bibi finds herself; obviously, it is this contradiction that cripples her motivation to seek education or at least a better life even after having a child out of wedlock. As she sinks deeper in torture and emotional pain, the trauma robs her of not just the physical resources to give her daughter the university education she had intended, but also her gusto to life. Clearly, the gradual brutalities, ruin and losses that communities surrounded by petroleum and petrochemical infrastructures grapple with over time constitute slow violence, and the attendant trauma has far-reaching consequences: “The day my mother's farmland was overrun by crude oil was the day her dream for me started to wither...I just wanted to leave the village. The sameness of life in the village would kill me if I did not escape" (Yellow-Yellow p. 10). Slow violence compels people to stretch their imaginations of what constitutes harm. It instructs them to pay serious attention to forms of violence that can spread or become contagions, as we find in the case of Zilayefa.

Although Rob Nixon (2011) insisted that slow violence is "spectacle deficient" (Slow violence, p. 47), a critical thinker is compelled to inquire: how true is that position? This interrogation is however born out of the understanding that Niger Delta suffers toxic pollutions and are exposed to the uncertainties of environmental abuses, and as such the experience cannot be said to be "spectacle deficient" since they are all witnesses to the horrors and tears; in fact, their response sometimes is usually laced in in violence:

Sometimes when I would sit outside with the boys and girls in my age group, we would listen to the radio, and sometimes we would hear an Ijaw person, living in Port Harcourt or Lagos, speaking about how the oil companies had destroyed our Niger Delta with impurity... these broadcasts drove the boys in my village to violence... some of them joined the boys from other villages to kidnap oil company executives... (Yellow-Yellow p. 9).

Certainly, the aftermath or product of this violent response, say kidnapping and militancy leaves the region neglected developmentally or in a never-ending circle of violence.

\section{The Gradual Destruction of the Woman}

Aside the deployment of the lamentation aesthetic, Agary pursues a vision of change. She presents a vision of a people, possessing the capacity to responsibly mobilize themselves for either a peaceful or violent protest with 
the clear objective of bringing about change. While Agary decries the option of violence which her Niger Delta people have suddenly been compelled to by their oppressors, she however, unsubscribe to it, insisting that it is not the ideal remedy to the problem. Violence is a deadly venture which depletes the Niger Delta communities, and it is avoidable when the operators of oil exploration activities decide to be more sensitive to the challenges and complaints of their host communities.

For ecofeminists, society should rise to the understanding of new ways of perceiving women's efforts that are aimed at creating and offering nourishments to both human and non-human nature. Therefore, female writers who possess a consciousness for the environment like Kaine Agary would intentionally subscribe to dialogue as a vehicle to change rather than crude violence. Through the writings of ecofeminists, "a close understanding of nature has helped the human race to sustain itself in every part of the world." (Merchant p. 55).

Like the physical environment, the woman sometimes suffers exploitation and plundering as we find in many African imaginative and real societies. Consequently, women movements across Africa, is committed towards correcting some, if not all the wrongs against women. The constituency of this agenda is controlled by women and its framework revolves around what Lowdter-Newton (2014) calls the "ideology of woman's sphere". By the "ideology of woman's sphere", Lowdter-Newton meant the specific difference between men and women. It is important to highlight the implicit moral aspect of the feminist method based on the recognition that it is wrong to thingify women or to relegate the woman to the backstage of social organization. But the reverse is what we find in many parts of Africa. In his estimation, Udumukwu (1998) observed that being a woman in Nigeria means being an object of inferiority, an object of desire and it is best summed up in the common expression often used to silence errant women: "be a woman." (p.131). He reasoned further that:

The reproach, "be a woman" used within the Nigerian context is indicative of a specific language game, a particular way of making a vocabulary model that is favourable to men...It is not used by men alone in Nigeria, but also by women. Women in Nigeria remind other women of their status...that excludes them by a process of acquiescence (p. 131).

In her inaugural lecture held in 2016, Chioma Opara painted the woman's situation using these words, “... when the woman is not directly battered, she is used as a means to a turbulent end" (p. 29).

But the question is, is the woman always a victim? Or, are there times when she is unarguably, a volunteer? A victim is somebody who is adversely affected by an action or circumstance; somebody who is tricked or exploited. But a volunteer is someone who willingly offers herself or her body for exploitation-especially when the exploitation comes in an appealing wrap. An African proverb tells us that an animal is caught in a trap by what it feeds on. But beyond the message of this proverb, there are women and girls who have voluntarily offered themselves up for varying shades of abuse. An abuser is sick, but often, his sickness is fueled by the passivity, compromise and co-operation of the abused. In their review of some of the female character in Agary's Ijaw communities in the Niger Delta region, Onukaogu and Onyerionwu (2011) observed that, "The girls, like Zilayefa, contemplated selling their bodies, while the boys think of other vices" ("Crisis and the literature" p.68). While there are some underlying factors that ignite an abuse, we are not aware of any justifiable factor that should sustain it; however, there are women who are silent and maybe, reluctant to resist abusers.

Zilayefa's meeting with Admiral Kenneth Amalayefa was friendly and relational from the start; but as time progress, it mutated in her mind into a conscious "use what she's got to get what she needed". At that point she ceases from being a victim of molestation to a volunteer for exploitation---a teenage one at that. Through this choice, she experiences chain of losses. Counting her losses, Ohagwam (2021) outlined them concisely:

Zilayefa's meeting with the Admiral was the early step she took in the adventure into self-contamination, self-exploitation and self-destruction. Aside being a promiscuous Ijaw son, Admiral stands tall among male figures whose stock-in-trade is the objectification of women, indeed, a chief in the practice of exploiting economically poor and socially-less privileged girls. Through this meeting, Zilayefa lost her innocence, her virginity, her unborn child and perhaps, put her womb at jeopardy (p. 112).

From the foregoing, we can insist that when young people, especially the female folks, impress on their impressionable psyches that they can make a living out of socially condemnable engagements, they cease from being victims to becoming volunteers.

\section{Conclusion}

The resistance we find in the literature of the Niger Delta, is the response expected of a victim. While dialogue is considered the healthiest of all, it should not be taken as weakness, but should mobilize all concerned parties to action in order to bring about change. Victimization, abuse and oppression thrive in secrecy; thus, when victims 
decide to keep mute or behave passive, society should no more refer to them as victims but as volunteers. However, through education, orientation and training, a volunteer in the context of this discourse can decide against volunteering. Education-whether formal or informal has the potential of redirecting some less advantaged women and girls from volunteering to crusading against abuses. When women get educated and earn for themselves, they become not only economically empowered but also less dependent on men. This reduces the possibility of becoming victims of sexual exploitation and patriarchal subjugation.

\section{References}

Agary, K. (2006). Yellow-Yellow. Yaba, Lagos: Dtalkshop.

Lawhead, F. W. (2002). Voyage of discovery: a historical introduction to philosophy. New York: Thomson Advantage Books.

Lowdter-Newton, J. (2014). Women, power, and subversion: social strategies in British fiction, 1778-1860. London: Methuen Press. https://doi.org/10.4324/9780203084793

Merchant, C. (2008). Eco-femminismo. La camera blu, 3(1), 48-58.

Miller, A. (2005). Death of salesman. UBSPD edition. New Delhi: UBS publishers.

Nixon, R. (2011). Slow violence and the environmentalism of the poor. Massachusetts: Harvard UP. https://doi.org/10.4159/harvard.9780674061194

Obi-Apoko, S. (2009). Floating Snag. Ibadan: Kraft Books.

Ohagwam, U. (2021). Slow violence and the visions of remediation in selected Niger Delta novels. (Unpublished doctoral dissertation). University of Port Harcourt, Port Harcourt, Nigeria

Onukaogu, A. A., \& Onyerionwu, E. (2011). Crisis and the Literature of the Niger Delta: The Dual Aesthetics of the Lachrymal and the Revolutionary. In C. Nwahunanya (Ed.), From Boom to Doom: Protest and Conflict Resolution in the Literature of the Niger Delta (pp. 66-69). Owerri: Springfield Publishers.

Opara, C (2016). Towards the integration in heterogeneity: poetics, conflict and gender politics in literature: An inaugural lecture series. Rivers State University of Science and Technology.

Udumukwu, O. (1998). Social responsibility in the Nigerian novel. Port Harcourt: Sherbrooke Associates.

\section{Copyrights}

Copyright for this article is retained by the author(s), with first publication rights granted to the journal.

This is an open-access article distributed under the terms and conditions of the Creative Commons Attribution license (http://creativecommons.org/licenses/by/4.0/). 